\title{
Analisis Kesulitan Kemampuan Representasi Matematis Siswa Ekstrovert Dalam Menyelesaikan Soal Matematika pada Materi Aljabar
}

\author{
Aulia Syafitri a, ${ }^{\star}$, Roseli Theis a,2, Dewi Iriani a,3 \\ ${ }^{a}$ Pendidikan Matematika Universitas Jambi, Jl. Raya Jambi Muara Bulian Km 15 Mendalo Indah Muaro Jambi, Jambi, Indonesia \\ ${ }^{1}$ Auliasyaftri.as02@gmail.com* \\ * Corresponding Author
}

Diterima 19 Maret 2021; Disetujui 20 Maret 2021; Diterbitkan 20 Maret 2021

\begin{abstract}
The objective of this study is to analyze the difficulty of representation ability Mathematical extrovert students in class VII-D in solving math problems on algebraic material, as well as knowing the factors that cause difficulties experienced by students in meet the indicators of mathematical representation ability. The ability of mathematical representations is measured based on Its aspects include visual representation aspects, expression representation aspects mathematics, and aspects of the representation of words or written text. This is qualitative research using a descriptive approach. This is carried out at SMP Negeri 22 Jambi with 4 students from class VII-D. The results showed that SE1, SE2, SE3 and SE4 are students with extrovert personalities do not have difficulty in the visual aspect. On aspects of representation of mathematical equations or expressions of Students SE1, SE3, and SE4 having difficulty making mathematical models or equations. On that aspect word or written text students SE2, SE3, and SE4 have difficulty when determine what steps will be taken to solve the problem mathematical. Factors causing difficulties in the mathematical representation ability are on visual aspects, representational aspects of mathematical expressions, and aspects of word representation or written text is a non-cognitive learning factor
\end{abstract}

\section{KEYWORDS}

Difficulty

Mathematical

representation ability

Extrovert

Problem

mathematics

\section{Pendahuluan}

Matematika merupakan ilmu yang dapat memicu berkembangnya kemampuan berpikir logis, kritis dan kreatif. Selain itu, matematika membantu memudahkan kita dalam perhitungan suatu masalah dalam berbagai bidang ilmu, misalnya ilmu ekonomi, fisika, kimia, dan yang lain. Oleh karena itu, matematika menjadi salah satu mata pelajaran wajib disetiap jenjang pendidikan, bahkan matematika menjadi salah satu mata pelajaran yang menjadi penentu kelulusan siswa di setiap jenjang pendidikan, baik pendidikan dasar, pendidikan menengah pertama ataupun pendidikan menengah atas.

Adapun tujuan dari pembelajaran matematika menurut Permendiknas No. 22 tahun 2006 adalah; (1) Memahami konsep matematika, menjelaskan keterkaitan antar konsep dan mengaplikasikan konsep atau logaritma, secara luwes, akurat, efisien, dan tepat, dalam pemecahan masalah. (2) Menggunakan penalaran pada pola dan sifat, melakukan manipulasi matematika dalam membuat generalisasi, menyusun bukti, atau menjelaskan gagasan dan pernyataan matematika. (3) Memecahkan masalah yang meliputi kemampuan memahami masalah, merancang model matematika, menyelesaikan model dan menafsirkan solusi yang diperoleh. (4) Mengkomunikasikan/ menyajikan kembali gagasan dengan simbol, tabel, diagram, atau media lain untuk memperjelas keadaan atau masalah. (5) Memiliki sikap menghargai kegunaan matematika dalam kehidupan, yaitu memiliki rasa ingin tahu, perhatian, dan minat dalam mempelajari matematika, serta sikap ulet dan percaya diri dalam pemecahan masalah.

Konsep-konsep dalam matematika terorganisir secara sistematis, logis dan hirarkis dari yang paling sederhana ke yang kompleks (Rumasoreng \& Sugiman, 2014). Beberapa karakteristik matematika yakni: (1) objek matematika adalah abstrak, (2) simbol-simbol kosong dari arti, (3) 
kesepakatan dan pemikiran deduktif aksiomatik, (4) taat asas atau kontradiksi, (5) kesemestaan sebagai pembatas pembahasan (Aminah \& Ayu Kurniawati, 2018). Berdasarkan karakteristik matematika tersebut. Secara umum letak kesulitan siswa dalam menyelesaikan soal cerita matematika adalah menemukan bentuk operasi yang harus digunakan, dalam hal ini cara atau metode dan beberapa siswa mengalami kesulitan dalam menalar bentuk soal-soal cerita karena kurang pemahaman dalam membaca dan intonasi membaca (Widyaningrum, 2016). Adanya kesulitan yang dialami siswa tersebut, maka hal ini dapat menyebabkan berpengaruhnya prestasi belajar siswa.

Menurut (Ixganda, 2015) Prestasi belajar merupakan variabel yang kompleks, artinya upaya peningkatan prestasi belajar dipengaruhi oleh beberapa faktor. Lebih lanjut lagi, Masing-masing faktor saling terkait dan tidak berdiri sendiri dalam mempengaruhi prestasi belajar. Secara umum ada dua faktor yang menyebabkan siswa mengalami kesulitan belajar, yaitu faktor yang berasal dari dalam diri siswa itu sendiri (internal) dan faktor yang berasal dari luar diri siswa (eksternal). Faktor yang berasal dari dalam diri siswa (internal) mencakup minat, motivasi, sikap belajar dan kesehatan fisik maupun kesehatan mental siswa. Sedangkan faktor yang berasal dari luar siswa (eksternal) antara lain dari lingkungan Sekolah, lingkungan keluarga, dan lingkungan masyarakat serta faktor media massa, sarana dan prasarana Sekolah.Menurut Eysenck membagi kepribadaian manusia menjadi dua tipe, introvert atau ekstrovert (dalam Azizah, 2017). Orang-orang yang termasuk dalam tipe introvert adalah individu yang berpusat pada dirinya sendiri, termasuk menentukan perilakunya sendiri. Sebaliknya, orang dengan tipe kepribadian ekstrovert cenderung mengarahkan dirinya pada lingkungan di sekitarnya, dan pada umumnya suka berteman, ramah, menyukai pesta, mempunyai banyak teman, membutuhkan orang lain untuk menjadi lawan bicara mereka, tidak suka membaca ataupun belajar sendirian, senang humor, selalu siap menjawab, menyukai perubahan dan santai (Dominika \& Virlia, 2018). Hal senada diungkapkan Zaman \& Abdillah, Kepribadian ekstrovert memiliki kelebihan yakni suka mengobrol dengan orang lain, cepat bertindak dan menyukai variasi tugas, sedangkan kelemahannya yakni bertindak langsung tanpa mempertimbangkan resiko, terlalu menyederhanakan situasi yang rumit dan kompleks, dan tidak memiliki cukup kesabaran untuk menghadapi tugas secara detail atau mendalam (Zaman \& Abdillah, 2009). Sehingga dalam hal ini siswa yang memiliki kepribadian ekstrovert berindikasi melakukan kesalahan dalam menyelesaikan tugas.

Menurut Soedjadi dalam (Widyaningrum, 2016) mengatakan bahwa kesulitan merupakan penyebab terjadinya kesalahan. Kesulitan yang dialami siswa perlu diidentifikasi yaitu dengan cara memberikan soal tes kemampuan representasi matematis yang menekankan suatu kemampuan visual, ekspresi matematis maupun teks atau kata-kata dan dengan melakukan wawancara kepada siswa. Oleh karena itu, perlu dilakukan analisis untuk mengetahui kesulitan kemampuan representasi matematis siswa ekstrovert dalam menyelesaikan soal matematika pada materi aljabar. Pokok pembahasan materi aljabar dipilih dengan alasan aljabar merupakan salah satu materi matematika yang sangat berkaitan dengan kehidupan sehari-hari dan juga dapat membantu peneliti dalam melihat kemampuan representasi matematis siswa.

\section{Metode Penelitian}

Penelitian ini termasuk jenis penelitian kualitatif deskriptif. Penelitian kualitatif adalah penelitian yang bermaksud untuk memahami fenomena tentang apa yang dialami oleh subjek penelitian misalnya prilaku, persepsi, motivasi, tindakan, dan lain-lain. Secara holistic, dan dengan cara deskripsi dalam bentuk kata-kata dan bahasa, pada suatu konteks khusus yang alamiah dan dengan memanfaatkan berbagai metode alamiah.

Adapun sumber data dalam penelitian ini adalah siswa kelas VII-D SMP N 22 Kota Jambi semester genap tahun ajaran 2019/ 2020. Pemilihan kelas berdasarkan hasil pertimbangan dan masukan dari wali kelas dan guru mata pelajaran. Pertimbangannya adalah kelas tersebut sebagian besar siswanya memperoleh nilai ulangan matematika materi aljabar dibawah rata-rata, sehingga dikelas tersebut dipercaya memiliki siswa yang dapat membantu peneliti pada proses penelitian.

Pada penelitian ini digunakan wawancara tidak terstruktur. Wawancara tidak terstruktur adalah wawancara yang bebas di mana peneliti tidak menggunakan pedoman wawancara yang telah tersusun secara sistematis dan lengkap untuk pengumpulan datanya. 


\section{Hasil dan pembahasan}

Penelitian ini membahas tentang kesulitan kemampuan representasi matematis siswa ekstrovert dalam menyelesaikan soal matematika materi Aljabar dikelas VII. Kemampuan Representasi yang di ukur pada penelitian ini meliputi 3 aspek, yaitu aspek representasi visual, aspek representasi persamaan atau ekspresi matematis dan aspek representasi kata atau teks tertulis.Berdasarkan hasil penelitian, baik melalui hasil jawaban tertulis maupun hasil wawancara, keempat subjek penelitian yang berkepribadian ekstrovert menunjukkan hasil yang berbeda-beda.

Untuk aspek pertama yaitu aspek representasi visual. Dalam aspek representasi visual ada 2 indikator yang seharusnya dimunculkan oleh subjek yakni menggunakan representasi visual untuk menyelesaikan masalah dan membuat bangun geometri untuk memperjelas masalah dan memfasilitasi penyelesaian. Berdasarkan deskripsi lembar jawaban soal kemampuan representasi matematis dan hasil wawancara, menunjukkan bahwa SE1, SE2, SE3, dan SE4 sudah mampu menyelesaikan tes kemampuan representasi matematis pada aspek visual. Dalam memenuhi indikator kemampuan representasi matematis pada aspek visual SE1, SE2, SE3, dan SE4 tidak mengalami adanya kesulitan.

Untuk aspek kedua yaitu aspek representasi persamaan atau ekspresi matematis. Dalam aspek representasi ekspresi matematis ada 2 indikator yang seharusnya dimunculkan oleh subjek yakni membuat persamaan atau model matematis dari representasi lain yang diberikan dan penyelesaian masalah melibatkan ekspresi matematis. Berdasarkan deskripsi lembar jawaban soal kemampuan representasi matematis dan hasil wawancara, menunjukkan bahwa tidak ada satupun subjek yang memenuhi 2 indikator tersebut.

Untuk indikator pertama yakni membuat persamaan atau model matematis dari representasi lain yang diberikan, hanya SE2 yang sudah mampu memenuhi indikator tersebut, dibuktikan dari jawaban SE2 yang sudah mampu membuat persamaan atau model matematis dari representasi yang diberikan secara benar. Berdasarkan wawancara terhadap SE2, peneliti tidak menemukan adanya kesulitan yang dialami dalam memenuhi indikator membuat persamaan atau model matematis dari representasi yang diberikan. Sementara tiga subjek lain yakni SE1, SE3, dan SE4 tidak mampu memenuhi indikator membuat persamaan atau model matematis dari representasi lain yang diberikan, dibuktikan dari jawaban ketiga subjek, belum ada yang mampu membuat persamaan atau model matematis secara benar. Seperti yang diungkapkan (Zaman \& Abdillah, 2009) bahwa seseorang eksktrovert terlalu menyederhanakan situasi rumit dan kompleks. Oleh karenanya, Berdasarkan hasil wawancara peneliti terhadap SE1, SE3, dan SE4, peneliti mendapatkan informasi bahwa ketiga subjek tersebut mengalami kesulitan dalam membuat persamaan atau model matematis dari representasi lain yang diberikan. Kesulitan yang dialami yaitu tidak mengerti saat guru menjelaskan tentang membuat model matematika dari soal cerita.jawaban. Hal ini sesuai dengan pendapat (Nengsih et al., 2016) Kemampuan berpikir siswa dapat ditumbuhkembangkan salah satunya melalui pemecahan masalah. Dengan pemecahan masalah seseorang akan dituntut untuk berpikir secara sistematis, kritis, logis, serta memiliki sikap pantang menyerah untuk menemukan solusi dari masalah yang dihadapi.

Untuk indikator kedua yakni penyelesaian masalah dengan melibatkan ekspresi matematis, SE1, SE3, dan SE4 sudah mampu memenuhi indikator tersebut dibuktikan dari jawaban ketiga subjek yang sudah melibatkan ekspresi matematis untuk penyelesaian masalah secara benar.Berdasarkan hasil wawancara peneliti terhadap SE1, SE3, dan SE4, peneliti tidak menemukan adanya kesulitan yang dialami subjek dalam memenuhi indikator penyelesaian masalah dengan melibatkan ekspresi matematis. Sementara SE2 tidak mampu memenuhi indikator penyelesaian masalah dengan melibatkan ekspresi matematis, dibuktikan dari lembar jawaban SE2 yang tidak mampu melanjutkan jawabannya hingga menemukan penyelesaian akhir. Berdasarkan hasil wawancara terhadap SE2, peneliti mendapatkan informasi bahwa SE2 mengalami kesulitan dalam memenuhi indikator penyelesaian masalah dengan melibatkan ekspresi matematis, kesulitan yang dialaminya adalah tidak mengetahui cara yang akan digunakan untuk melanjutkan/ menyelesaikan permasalahan dari model matematis yang di buat. Hal ini sesuai dengan pendapat (Nor Diana Natasya \& Rusdial Marta, 2019) Kesulitan belajar adalah ketidakmampuan siswa dalam menguasai fakta, konsep, prinsip dan keterampilan. 
Dalam aspek representasi kata atau teks tertulis ada 3 indikator yang seharusnya dimunculkan oleh subjek yakni membuat situasi masalah berdasarkan data atau representasi yang diberikan, menulis langkah-langkah penyelesaian masalah matematis dengan kata-kata, dan menulis interpretasi dari suatu representasi yang diberikan. Berdasarkan deskripsi lembar jawaban soal kemampuan representasi matematis dan hasil wawancara, menunjukkan bahwa tidak ada satupun subjek yang memenuhi 3 indikator tersebut.

Untuk indikator pertama yakni membuat situasi masalah berdasarkan data atau representasi yang diberikan. SE1, SE2, dan SE3 sudah mampu memenuhi indikator tersebut dibuktikan dari jawaban ketiga subjek yang sudah mampu membuat situasi masalah berdasarkan data atau reprsentasi yang diberikan secara lengkap dan benar.Berdasarkan hasil wawancara peneliti terhadap SE1, SE2, dan SE3, peneliti tidak menemukan adanya kesulitan yang dialami ketiga subjek dalam memenuhi indikator membuat situasi masalah berdasarkan data atau representasi yang diberikan. Sementara SE4 tidak mampu memenuhi indikator membuat situasi masalah berdasarkan data atau representasi yang diberikan, dibuktikan dari jawaban, SE4 belum mampu membuat situasi masalah berdasarkan data yang diberikan. Berdasarkan hasil wawancara peneliti terhadap SE4, peneliti mendapatkan informasi bahwa SE4 mengalami kesulitan saat membuat situasi masalah berdasarkan data atau representasi yang diberikan. Kesulitan yang dialami SE4 yaitu tidak memperhatikan saat guru menjelaskan terkait penyelesaian masalah mengginakan soal cerita, dan SE4 tidak terbiasa mengerjakan soal dalam bentuk cerita. Hal ini sesuai dengan pendapat (Karunia Suci, 2016) mengatakan bahwa pada tahap pemahaman kesalahan yang dilakukan siswa adalah dalam mengubah konteks masalah soal cerita menjadi bahasa sendiri yang berpengaruh pada proses penyelesaian soal.

Untuk indikator kedua yakni menulis langkah-langkah penyelesaian masalah matematis dengan kata-kata, hanya SE1 yang sudah mampu memenuhi indikator tersebut, dibuktikan dengan jawaban SE1 yang sudah mampu menuliskan langkah-langkah penyelesaian masalah matematis dengan katakata secara lengkap dan benar. Berdasarkan hasil wawancaa peneliti terhadap SE1, peneliti tidak menemukan adanya kesulitan yang dialami SE1 dalam memenuhi indikator menulis langkahlangkah penyelesaian masalah matematis degan kata-kata. Sementara ketiga subjek lain yakni SE2, SE3, dan SE4 tidak mampu memenuhi indikator menulis langkah-langkah penyelesaian masalah matematis dengan kata-kata, dibuktikan dari jawaban ketiga subjek, tidak ada yang mampu menuliskan langkah-langkah penyelesaian masalah secara benar. Berdasarkan hasil wawancara peneliti terhadap SE2, SE3, dan SE4, peneliti mendapatkan informasi bahwa ketiga subjek tersebut mengalami kesulitan saat menulis langkah-langkah penyelesaian masalah dengan kata-kata. Kesulitan yang dialami yaitu tidak mengetahui langkah-langkah yang akan dilakukannya untuk menyelesaikan permasalahan yang diberikan. Menurut (Utari et al., 2019) kesulitan yang sering dialami oleh siswa yaitu kesulitan saat mengerjakan soal cerita karena kurang mampu memahami maksud soal dan kebingungan saat menentukan operasi hitung yang akan dipakai.

Untuk indikator ketiga yakni menulis interpretasi dari suatu representasi, SE3 dan SE4 telah mampu memenuhi indikator tersebut, dibuktikan dengan jawaban SE3 dan SE4 yang sudah mampu menuliskan interpretasi dari suatu representasi secara lengkap dan benar. Berdasarkan wawancara peneliti terhadap SE3 dan SE4, peneliti tidak menemukan adanya kesulitan yang dialami SE3 dan SE4 dalam memenuhi indikator menulis interpretasi dari suatu representasi. Sementara dua subjek lain yakni SE1 dan SE2 tidak mampu memenuhi indikator menulis interpretasi dari suatu representasi, dibuktikan dengan jawaban SE1 dan SE2 tidak mampu menuliskan interpretasi dari suatu representasi secara lengkap dan benar. Berdasarkan wawancara peneliti terhadap SE1 dan SE2, peneliti mendapatkan informasi bahwa kedua subjek mengalami kesulitan saat menulis interpretasi dari suatu representasi. Kesulitan yang dialami SE1 dan SE2 yaitu tidak terbiasa menuliskan kesimpulan akhir saat menyelesaikan soal terutama soal cerita. Menurut (Trapsilasiwi et al., 2016) pemecahan masalah dalam matematika sekolah biasanya diwujudkan melalui soal cerita. Lebih lanjut (Yusnia \& Fitriyani, 2010) Faktor utama terjadi kesalahan pada setiap butir soal adalah karena siswa tidak terbiasa menerima soal bentuk cerita, sehingga sebagian besar siswa belum menguasai bagaimana tahapan penyelesaian yang sesuai dengan permintaan soal.

Untuk aspek pertama yaitu aspek Representasi kata atau teks tertulis. Dalam aspek representasi kata atau teks tertulis ada 3 indikator yang seharusnya dimunculkan oleh subjek yakni membuat situasi masalah berdasarkan data atau representasi yang diberikan, menulis langkah-langkah penyelesaian masalah matematis dengan kata-kata, dan menulis interpretasi dari suatu representasi yang diberikan. Berdasarkan deskripsi lembar jawaban soal kemampuan representasi matematis dan 
hasil wawancara, menunjukkan bahwa tidak ada satupun subjek yang memenuhi 3 indikator tersebut.

Untuk indikator pertama yakni membuat situasi masalah berdasarkan data atau representasi yang diberikan. SE1, SE2, dan SE3 sudah mampu memenuhi indikator tersebut dibuktikan dari jawaban ketiga subjek yang sudah mampu membuat situasi masalah berdasarkan data atau reprsentasi yang diberikan secara lengkap dan benar. Berdasarkan hasil wawancara peneliti terhadap SE1, SE2, dan SE3, peneliti tidak menemukan adanya kesulitan yang dialami ketiga subjek dalam memenuhi indikator membuat situasi masalah berdasarkan data atau representasi yang diberikan. Sementara SE4 tidak mampu memenuhi indikator membuat situasi masalah berdasarkan data atau representasi yang diberikan, dibuktikan dari jawaban, SE4 belum mampu membuat situasi masalah berdasarkan data yang diberikan. Berdasarkan hasil wawancara peneliti terhadap SE4, peneliti mendapatkan informasi bahwa SE4 mengalami kesulitan saat membuat situasi masalah berdasarkan data atau representasi yang diberikan. Kesulitan yang dialami SE4 yaitu tidak memperhatikan saat guru menjelaskan terkait penyelesaian masalah mengginakan soal cerita, dan SE4 tidak terbiasa mengerjakan soal dalam bentuk cerita. Hal ini sesuai dengan pendapat (Yusnia \& Fitriyani, 2010) mengatakan bahwa mengerti konteks soal namun tidak dapat menuliskan makna secara tepat, kurang teliti, tidak memahami arti keseluruhan soal dengan baik sehingga tidak konsisten dalam mengidentifikasi hal yang diketahui, serta kurang tepat menangkap informasi yang terkandung dalam soal.

Untuk indikator kedua yakni menulis langkah-langkah penyelesaian masalah matematis dengan kata-kata, hanya SE1 yang sudah mampu memenuhi indikator tersebut, dibuktikan dengan jawaban SE1 yang sudah mampu menuliskan langkah-langkah penyelesaian masalah matematis dengan katakata secara lengkap dan benar. Berdasarkan hasil wawancaa peneliti terhadap SE1, peneliti tidak menemukan adanya kesulitan yang dialami SE1 dalam memenuhi indikator menulis langkahlangkah penyelesaian masalah matematis degan kata-kata. Sementara ketiga subjek lain yakni SE2, SE3, dan SE4 tidak mampu memenuhi indikator menulis langkah-langkah penyelesaian masalah matematis dengan kata-kata, dibuktikan dari jawaban ketiga subjek, tidak ada yang mampu menuliskan langkah-langkah penyelesaian masalah secara benar. Berdasarkan hasil wawancara peneliti terhadap SE2, SE3, dan SE4, peneliti mendapatkan informasi bahwa ketiga subjek tersebut mengalami kesulitan saat menulis langkah-langkah penyelesaian masalah dengan kata-kata. Kesulitan yang dialami yaitu tidak mengetahui langkah-langkah yang akan dilakukannya untuk menyelesaikan permasalahan yang diberikan. Menurut (Yulianty, 2019) Pemahaman terhadap konsep-konsep matematika merupakan dasar untuk belajar matematika secara bermakna.

Untuk indikator ketiga yakni menulis interpretasi dari suatu representasi, SE3 dan SE4 telah mampu memenuhi indikator tersebut, dibuktikan dengan jawaban SE3 dan SE4 yang sudah mampu menuliskan interpretasi dari suatu representasi secara lengkap dan benar. Berdasarkan wawancara peneliti terhadap SE3 dan SE4, peneliti tidak menemukan adanya kesulitan yang dialami SE3 dan SE4 dalam memenuhi indikator menulis interpretasi dari suatu representasi. Sementara dua subjek lain yakni SE1 dan SE2 tidak mampu memenuhi indikator menulis interpretasi dari suatu representasi, dibuktikan dengan jawaban SE1 dan SE2 tidak mampu menuliskan interpretasi dari suatu representasi secara lengkap dan benar. Berdasarkan wawancara peneliti terhadap SE1 dan SE2, peneliti mendapatkan informasi bahwa kedua subjek mengalami kesulitan saat menulis interpretasi dari suatu representasi. Kesulitan yang dialami SE1 dan SE2 yaitu tidak terbiasa menuliskan kesimpulan akhir saat menyelesaikan soal terutama soal cerita.

\section{Simpulan}

Pada aspek visual, siswa SE1, SE2, SE3, dan SE4 yang memiliki kepribadian ekstrovert tidak mengalami kesulitan pada aspek visual dalam kemampuan representasi matematis Pada Aspek Representasi persamaan atau ekspresi matematis Siswa SE1, SE3, dan SE4 mengalami kesulitan dalam memenuhi indikator persamaan atau model matematis dari representasi lain yang diberikan. Pada aspek kata atau teks tertulis siswa SE2, SE3, dan SE4 mengalami kesulitan dalam memenuhi indicator menulis langkah-langkah penyelesaian masalah matematis dengan kata-kata. Adapun faktor-faktor pada aspek persamaan atau ekspresi matematis yaitu tidak mengerti saat guru menjelaskan tentang membuat model matematika dari soal cerita dan pada aspek representasi kata 
atau teks tertulis kesulitan yang dialami SE1 yaitu tidak terbiasa menuliskan kesimpulan akhir saat menyelesaikan soal terutama soal cerita. Kesulitan yang dialami SE2 pada aspek persamaan atau ekspresi matematis yaitu tidak mengetahui cara yang akan digunakan untuk melanjutkan/ menyelesaikan permasalahan dari model matematis yang dibuat dan pada aspek representasi kata atau teks tertulis kesulitan yang dialami SE2 yaitu tidak mengetahui langkah-langkah yang akan dilakukan untuk menyelesaikan permasaahan yang diberikan dan tidak terbiasa menuliskan kesimpulan akhir saat menyelesaikan soal. Kesulitan yang dialami SE3 pada aspek persamaan atau ekspresi matematis yaitu tidak mengerti saat guru menjelaskan tenatng membuat model matematika dari soal cerita dan pada aspek representasi kata atau teks tertulis kesulitan yang dialami SE3 yaitu tidak mengetahui langkah-langkah yang akan dilakukannya untuk menyelesaikan permasalahan yang diberikan. Kesulitan yang dialami SE4 pada aspek representasi persamaan atau ekspresi matematis yaitu tidak mengerti saat guru menjelaskan tentang membuat model matematika dari soal cerita dan pada aspek representasi kata atau teks tertulis kesulitan yang dialami SE4 yaitu tidak memperhatikan guru saat menjelaskan terkait permasalahan soal cerita dan tidak mengetahui langkah-lankah yang akan dilakukannya untuk menyelesaikan permasalahan yang diberikan. Faktorfaktor kesulitan yang dialami subjek termasuk kedalam faktor nonkognitif belajar. Sedangkan dari segi kepribadian khusunya kepribadian ekstrovert juga mempengaruhi kesulitan kemampuan representasi matematis yang dialami keempat subjek, karena keempat subjek tidak terbiasa mengerjakan soal secara individu.

\section{Referensi}

Aminah, A., \& Ayu Kurniawati, K. R. (2018). Analisis Kesulitan Siswa Dalam Menyelesaikan Soal Cerita Matematika Topik Pecahan Ditinjau Dari Gender. JTAM|Jurnal Teori Dan Aplikasi Matematika, 2(2), 118. https://doi.org/10.31764/jtam.v2i2.713

Azizah, N. (2017). PENGARUH TIPE KEPRIBADIAN DAN PERBEDAAN JENIS KELAMIN Terhadap Hasil Belajar Mata Kuliah Micro Konseling Pada Mahasiswa Jurusan Dakwah STAIN Purwokerto. Hikmah, 8(2), 51-74.

Dominika, \& Virlia, S. (2018). Hubungan kepribadian ekstrovert-introvert dan penerimaan sosial terhadap siswa difabel pada siswa. Konselor, 7(1), 31-39. https://doi.org/10.24036/02018718735-0-00

Ixganda, O. (2015). Analisis Deskriptif Faktor Penyebab Kesulitan Belajar Pada Mata Pelajaran Chassis Dan Pemindah Daya Siswa Kelas Xi Program Keahlian Teknik Kendaraan Ringan. Jurnal Pendidikan Teknik Mesin Unnes, 15(2), 128410.

Karunia Suci, A. D. (2016). Analisis Kesalahan Siswa dalam Menyelesaikan Soal Cerita Matematika Berdasarkan Tahapan Newman. Ekuivalen Universitas Muhammadiyah Purworejo E-ISSN 2541-4070, 2(1), 19-24.

Nengsih, L. W., Susiswo, \& Sa'dijah, C. (2016). Kemampuan Pemecahan Masalah Matematika Siswa Sekolah Dasar dengan Gaya Kognitif Field Dependent. EduHumaniora | Jurnal Pendidikan Dasar Kampus Cibiru, 3(2), 143-148. https://doi.org/10.17509/eh.v3i2.2807

Nor Diana Natasya, Y. F. S., \& Rusdial Marta. (2019). ANALISISFAKTORPENYEBABKESULITANBELAJARMATEMATIKADI KELASIVSEKOLAHDASARNEGERI004BANGKINANGKOTA(MATERI PECAHAN). Jurnal Riset Pembelajaran Matematika Sekolah, 3.

Rumasoreng, M. I., \& Sugiman, S. (2014). Analisis Kesulitan Matematika Siswa Sma/Ma Dalam Menyelesaikan Soal Setara Un Di Kabupaten Maluku Tengah. Jurnal Riset Pendidikan Matematika, 1(1), 22. https://doi.org/10.21831/jrpm.v1i1.2661

Trapsilasiwi, D., Setiawani, S., \& Ummah, I. K. (2016). Analisis Kesalahan Pengolahan Matematika dalam Menyelesaikan Masalah Lingkaran. Jurnal Pancaran Pendidikan, 5(4), 159-168.

Utari, D. R., Wardana, M. Y. S., \& Damayani, A. T. (2019). Analisis Kesulitan Belajar Matematika dalam Menyelesaikan Soal Cerita. Jurnal Ilmiah Sekolah Dasar, 3(4), 545. 
https://doi.org/10.23887/jisd.v3i4.22311

Widyaningrum, A. (2016). ANALISIS KESULITAN SISWA DALAM MENGERJAKANSOAL CERITA MATEMATIKA MATERI ARITMATIKA SOSIAL DITINJAU DARI GAYA BELAJAR SISWA KELAS VII SMP NEGERI 5 METRO TAHUN PELAJARAN 2015/2016. Iqra', 1(June), 165-190.

Yulianty, N. (2019). Kemampuan Pemahaman Konsep Matematika Siswa Dengan Pendekatan Pembelajaran Matematika Realistik. Jurnal Pendidikan Matematika Raflesia, 4(1), 60-65. https://doi.org/10.33449/jpmr.v4i1.7530

Yusnia, D., \& Fitriyani, H. (2010). Identifikasi kesalahan siswa menggunakan Newman's Error Analysis (NEA) pada pemecahan masalah operasi hitung bentuk aljabar. Seminar Nasional Pendidikan, Sains Dan Teknologi Fakultas Matematika Dan Ilmu Pengetahuan Alam Universitas Muhammadiyah Semarang, 78-83.

Zaman, S., \& Abdillah, S. (2009). Cara Menggali Potensi Diri Untuk Meraih Kesempatan Kerja. Transmedia Pustaka. 